EJMBE

31,1

Received 26 November 2019 Revised 30 October 2020 5 February 2021

30 April 2021

Accepted 6 June 2021

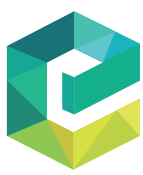

European Journal of Management and Business Economics Vol. 31 No. 1,2022 pp. $40-56$

Emerald Publishing Limited e-ISSN: 2444-8494

p-ISSN: $2444-8451$

DOI 10.1108/EJMBE-11-2019-0213

\section{Innovative outcome through exploration and exploitation - Enablers, barriers and industrial property}

\author{
Nancy Vargas \\ Instituto de Telecomunicaciones y Aplicaciones Multimedia, \\ Universitat Politècnica de València, Valencia, Spain \\ M. Begoña Lloria \\ Dirección de Empresas, Facultat d'Economia, Universitat de Valencia, \\ Valencia, Spain, and \\ Addisson Salazar and Luis Vergara \\ Instituto de Telecomunicaciones y Aplicaciones Multimedia, \\ Universitat Politènica de Valencia, Valencia, Spain
}

\begin{abstract}
Purpose - This research aims to study the effect of R\&D (research and development) enablers and barriers as well as industrial property on exploration, their influence on exploitation and finally the possible impact on innovative outcome $(\mathrm{IO})$ as a result variable. The $\mathrm{IO}$ can be defined as the orientation towards new or improved products, services and processes, as well as towards penetration and greater market share, which the company has obtained as a result of innovative processes.

Design/methodology/approach - For this purpose, a new relationship model is defined, which is empirically contrasted in a quantitative study. We use a sample of large firms from different economic sectors with a high level of investment in R\&D.

Findings - The results indicate a close relationship between exploration and exploitation processes, as well as a positive impact on the innovative outcome. Moreover, the type of relationship that R\&D enablers and barriers have with exploration is demonstrated and the lack of a positive effect of industrial property on exploration. Practical implications - These results may lead to new markets opening up and the creation or improvement of new products, services or processes in diverse sectors of highly innovative firms.

Originality/value - This research aims to study the effect of R\&D enablers and barriers and industrial property on learning flows and, finally, the possible impact on the innovative outcome. A new theoretical model of relationships is defined, and it is the first time that it is empirically tested.
\end{abstract}

Keywords R\&D enablers and barriers, Industrial property, Exploration, Exploitation, Innovative outcome Paper type Research paper

\footnotetext{
(C) Nancy Vargas, M. Begoña Lloria, Addisson Salazar and Luis Vergara. Published in European Journal of Management and Business Economics. Published by Emerald Publishing Limited. This article is published under the Creative Commons Attribution (CC BY 4.0) licence. Anyone may reproduce, distribute, translate and create derivative works of this article (for both commercial and non-commercial purposes), subject to full attribution to the original publication and authors. The full terms of this licence may be seen at http://creativecommons.org/licences/by/4.0/legalcode

The authors are thankful to Spanish Administration and European Union under grant TEC201784743-P.

This research is part of the Project ECO 2015-71380-R funded by the Spanish Ministry of Economy, Industry and Competitiveness and the State Research Agency. It was co-financed by the European Regional Development Fund (ERDF).
} 


\section{Introduction}

Innovation is an activity that is difficult to predict. New products or services or the solutions to problems associated with them are developed through complex, indeterminate processes. However, innovations are important for firms involved in technological activity since they have the potential to open up new markets and products, services or processes that are necessary in a competitive environment such as the current one (Maggitti et al., 2013; Ringberg et al., 2019).

In general, firms can produce new products or services because they explore completely new areas that shift away from their current knowledge base or because they turn current knowledge into new knowledge. Today's literature about the search for innovation based on organisational learning is well-known, with two different but complementary focuses: one on exploration and another on exploitation (Wilden et al., 2018).

Through the focus on exploration, the variety of the search extends to new areas, resulting in innovative products or services (Randhawa et al., 2016). However, the expected returns may spread out over time and, as a consequence, the probability of new inventions, too (March, 1991).

On the other hand, by focusing on the exploitation of the firm's current knowledge, the returns for the firm can be relatively high because the value of the knowledge is already known and can, therefore, increase the frequency of creating new products or services (Knight and Harvey, 2015). In summary, when the search is more exploratory, the results will be more innovative but not more reliable, and when the search is more exploitative, the results will be less innovative but more efficient (Wang and Hsu, 2014; Katila and Chen, 2008).

The value of innovative processes focusing on exploration and exploitation processes to obtain an innovative outcome (IO) has been studied. IO has been defined as new products, services or processes (or improvements) that the organisation has obtained as a result of an innovative process (Crossan and Apaydin, 2010; Vargas et al., 2018). Some empirical studies have shown that firms that explore generate new and more innovative technologies in the long term but infrequently (Greve, 2007). On the other hand, firms that exploit generate new technologies in the short term and do so more frequently (Katila, 2002). However, few works have studied the relationship between exploration and exploitation in a direct way.

This paper contributes to an analysis of the relationship between exploration, exploitation and IO in four important ways.

Firstly, previous studies have only partially analysed the relationship between exploration and exploitation (Guisado-González et al., 2017). Some of them have considered both as independent activities with no relationship, for example, Voss et al. (2008) or Jansen et al. (2009). Other studies accept the existence of a relationship whereby one substitutes the other because they need to compete for the company's scarce resources (Laursen et al., 2010; Lavie et al., 2011). Finally, other authors have considered the two learning flows as complementary with a range of combinations. These combinations are called ambidexterity in much of the literature in this area (Raisch and Birkinshaw, 2008; O'Reilly and Tushman, 2013; Asif and Vries, 2014; Parida et al.,2016; Tian et al., 2020; Wolf et al., 2019). However, in this paper, we present and test the direct relationship between exploration and exploitation, with good results.

Secondly, other works propose theoretical models that are original but which, in the end, are not empirically contrasted in quantitative or qualitative studies. Thus, this area remains a topic of interest in research (Katila and Chen, 2008; Crossan and Apaydin, 2010; Teece, 2012; Vargas et al., 2018; Wilden et al., 2018). In this paper, then, we empirically test our new model in a quantitative study with significant conclusions.

Thirdly, most studies include organisational performance as a final variable (Lubatkin et al., 2006; Raisch and Birkinshaw, 2008; Parida et al., 2016; Arzubiaga et al., 2020). However, we are more specific, and we work with a new variable called IO. (Crossan and Apaydin, 2010; Vargas et al., 2018).
Innovative outcome through exploration 
EJMBE 31,1
Fourthly, in this paper, we will include other variables such as enablers, R\&D barriers and industrial property and study their effect on exploration and exploitation, including the effect on IO as a result variable. For this purpose, a new theoretical model of relationships is defined that is empirically contrasted.

The structure of the paper is as follows. Firstly, the theoretical framework is presented, where exploitation and exploration are defined, as well as the variables that define R\&D enablers, barriers, and industrial property and their effect on the IO. Their fundamental relationships are studied and transposed into a theoretical model. Next, the hypotheses to be tested are presented. These hypotheses are tested in a quantitative study in highly innovative firms with high spending on R\&D. There are firms in the economic sectors of software and telecommunications, pharmaceuticals, space aeronautics construction and more. Finally, the most relevant results, discussion and conclusions are presented, as well as some of the main limitations and future lines of research.

\section{Theoretical background}

In this first section, we will develop the theoretical framework and define the variables, which will serve as the basis to build our theoretical model of relationships.

\subsection{Exploitation and exploration}

The tasks of R\&D are characterised fundamentally by their complexity and by the heavy investment they demand. Both aspects require a search for enablers (especially for economic investment), overcoming important barriers and protecting the new knowledge generated. In this context, there is also a need to generate learning flows, both internally and externally, to help transfer technological knowledge (Crossan and Apaydin, 2010). These constant and iterative learning flows in all directions lead to innovative processes that, in the medium or long term, enable the company to increase its competitiveness. In addition, they are a condition for sustained change in the state of knowledge of an individual or an organisation, and they represent the transformation of both the way of thinking about things and how to do them within the organisation. Argyris and Schön (1978) and Crossan et al. (1999) define these learning flows as the transfer and dissemination of knowledge within and across the boundaries of the organisation.

On this basis, learning flows allow firms to explore new knowledge and exploit existing knowledge to innovate more and better (Benitez et al., 2018). Two important processes emerge: exploration and exploitation, which involve two different learning activities.

The main objective of exploitation is to take advantage of exploiting local knowledge within the limits of what is known, and the activity is more geared towards the selection and standardisation of successful practices. For this reason, the activity of exploitation does not generate originality but stability and the reinforcement of the routines. The flow of learning related to this flow indicates the way in which institutionalised learning affects individuals and groups. It is the process for taking advantage of what exists, focusing resources on improving products and processes; therefore, it includes aspects such as refinement, choice, production, efficiency, selection, implementation and execution (March, 1991).

Exploration, on the other hand, indicates practices that seek and experiment with new knowledge. In other words, this learning flow is related to the transfer of learning from individuals and groups that becomes embedded or institutionalised in the organisation in the form of systems, structures, strategies and procedures (Hedberg, 1981; Shrivastava, 1983).

Along these lines, some authors recognise the exploitation process as an internal function in the company's main dimension (exploitation of existing resources) and the exploration process as a purpose dimension, a fundamentally external function (Marín-Idárraga et al., 
2016). Exploitation also implies refining the internal resources that give rise to more routines and more control. It, therefore, helps a company to innovate more, but it hinders high-impact innovation (Greve, 2007). Exploration, on the other hand, involves research into processes and scientific searches. It allows a company to develop high-impact innovations (Danneels, 2002; March, 1996). This includes elements such as searches, variation, risk-taking, experimentation, play, flexibility, discovery and innovation (March, 1991). These elements are associated with possibilities for development beyond the organisational limits, and therefore, they imply relationships with the environment in which the company seeks to absorb new knowledge (Lavie and Rosenkopf. 2006: Bierly et al., 2009; Lloria and Peris-Ortiz, 2014; Peeters and Martin, 2017).

Exchanges between the two processes are inevitable because the two types of learning require orientations, strategies, capacities but substantially different structures (Bauer and Leker, 2013). Both processes are important in the company, but their presence can generate a dilemma to a greater or lesser degree (March, 1996, 2006).

The central aspect of the distinction between the processes of exploration and exploitation, and their relationship with the IO, lies in whether it is better for the organisation to adopt an orientation. This allows the organisation to use its knowledge in the search for improvements within an established framework (i.e. exploitation) to pursue an orientation based on refreshing knowledge towards exploration.

In conclusion, recognising and managing the tension between exploitation and exploration is not an easy task; they are both critical challenges in the theory of organisational learning (Crossan et al., 1999). Therefore, one key aspect in our research is that an organisation should be involved in sufficient exploitation to guarantee its current viability while devoting sufficient attention to exploration to ensure the organisation's future viability (Levinthal and March, 1993). Some studies have used the notion of ambidexterity to refer to the balance between exploration and exploitation (Simsek et al., 2009; O'Reilly and Tushman, 2013; Hill and Birkinshaw, 2014; D'Souza et al., 2017 and others). Other authors simply suggest that ambidexterity is only an approach to explore and exploit simultaneously (Lavie et al., 2010).

\section{$2.2 R \& D$ enablers and barriers, industrial property and their effect on exploration}

Having explained the concepts of exploration and exploitation and the need to apply them to some extent simultaneously in organisations, we will now define other variables that will help us create our theoretical model. These independent variables are R\&D enablers, R\&D barriers, industrial property and IO as a result variable.

The tangible and intangible investment in R\&D enablers, such as financial resources, equipment, advanced software and hardware or qualified staff, can be considered to be today's challenges to innovative firms (March, 1991; Lee et al., 2018), yet the high costs of exploratory R\&D projects are necessary for exploratory activities. In the same vein, Dominguez and Massaroli (2018) show that exploration processes are affected by the use of information technology systems, the autonomy of researchers and learning culture. There are studies that look into investment as an enabler of R\&D and relate investment to the performance of exploratory innovation, concluding that spending on resources, in terms of both finance and qualified personnel, is essential and facilitates the innovative processes (Basu et al., 2011; Lee et al., 2018). Likewise, investment in innovation has been related to exploratory learning outcomes in order to achieve the most efficient method for firms (Battistini et al., 2013). The contemporary vision proposes that R\&D enablers provide strong support for success in exploration activities, contributing to the organisation by encouraging the creation of new ideas and knowledge while generating a more innovative context. Finally, innovative activity, when successful, generates profits from internal resources, which allows
Innovative outcome through exploration 
EJMBE 31,1 firms to overcome the barriers associated with financing innovative projects and reduces dependence on external financial sources (Castillo-Merino et al., 2010).

Based on these statements, we propose the first hypothesis of this study.

\section{H1. R\&D Enablers have a positive impact on exploration.}

During the R\&D process, firms are forced to face numerous challenges, impediments and obstacles. These are often called innovation barriers (D'Este et al., 2012; Sandberg and Aarikka-Stenroos, 2014). Research on barriers to innovation has been scarce. However, this approach to barriers is particularly useful since it allows potential specific problems to be identified that can potentially affect innovation, as explained by Hölzl and Janger (2012). Paradoxically, the latter affirms that barriers can be considered advantageous since they filter out the most unrealistic innovation projects and help identify resources for the objectives of the project that is to be carried out.

In Kleijnen et al. (2009), infrastructure barriers, financing, qualified training of R\&D workers, technological information, state activity in $R \& D$ and other factors are considered to be some of the barriers for firms. Nevertheless, the barriers within innovative firms may mostly be economical due to the expense of trying out new solutions and methods (Mancusi and Vezzulli, 2014). Firms that invest in the challenge of innovations generate barriers related to the uncertainty of success. Innovative firms are repeatedly exposed to various types of barriers; hence, the importance of research into the barriers' influence on exploration or exploitation processes is an issue today (Dougherty, 1992; Coad et al., 2016; Das et al., 2017).

Based on these works, we can propose hypothesis 2.

H2. R\&D barriers have a negative impact on exploration.

Innovative companies face a fundamental challenge of competitive advantages, which, in the end, is the search, for knowledge entails the propensity to fail, for imitation and mobility. In this environment, industrial property (IP) is a strategic field as a mechanism to protect inventions (Somaya, 2012; Holgersson and Wallin, 2017; Modic et al., 2019).

Innovative firms with patents increase their capacity to attract greater financing or external investment through a re-evaluation of their assets. Patents make it possible or help firms access external resources and foreign markets, for example, through transfer agreements or patent licences (Großmann et al., 2016). Patents could also be interpreted as an intermediate result of R\&D expenditure (Hsu and Ziedonis, 2013). The development of new products requires a broad set of highly specialised technologies, knowledge and skills that are difficult to create internally (Iansiti, 1997). IP such as patents is a source of detailed scientific knowledge-sharing, allowing key knowledge to be extracted about the materials, processes, functions, parameters, considerations and restrictions of proven innovations (Shapiro, 2001). Exploration into the applicability of IP for analysis and decisions in the design stages could help reduce the time it takes to analyse new knowledge through the use of existing information processing (Rosenkopf and Nerkar, 2001; Agarwal et al., 2009). Likewise, Wang et al. (2017) and Cammarano et al. (2017) have identified that IP and exploration activities have a good influence on innovation implementation. Furthermore, a relationship was found between the number of IPs, classified by exploration activities, with R\&D costs and their positive influence on the value of the share price (Yu and Hong, 2016). Based on these arguments, we can pose hypothesis 3 of this study.

H3. Industrial property (IP) has a positive effect on exploration.

\subsection{Innovative outcome (IO) as a result variable}

$\mathrm{R} \& \mathrm{D}$ is a source of corporate competitiveness and, at the same time, a challenge for the company. Today's competition in business is greater (fiercer) and more uncertain than in the past. For large firms, it is almost impossible to have R\&D advantages in all fields because, 
generally, there are limits to their resources, and they cannot neglect the R\&D barriers $(\mathrm{Xu}$, 2014). That said, once firms are involved in R\&D processes, the IO is the endpoint of those processes, and it can be defined as new products, services or processes (or improvements) that the organisation has obtained as a result of an innovative process (Crossan and Apaydin, 2010; Vargas et al., 2018).

According to the literature, the capacity for innovation is the most important determinant of performance in business profits. It is based on a positive relationship between a firm's innovation and profitability measures in order to generate profits (Ramadani et al., 2017). However, there are a few studies available that have looked quantitatively into the effects of exploration and exploitation on IO (Lavie et al., 2010). Among the studies that consider IO to be a key dependent variable for empirical study are the following: Pati and Garud (2020), Vargas and Lloria (2019), Vargas et al. (2018), Guisado-González et al. (2017) and Crossan and Apaydin (2010). We have considered these previous works as the background for this research.

Authors such as Ahuja and Katila (2001), Rosenkopf and Nerkar (2001), Wang and Li (2008) and others have stated that the IO has a different effect depending on the exploration or exploitation activities. For their part, Quintana-García and Benavides-Velasco (2008) affirm that IO has a stronger effect on exploration activity than on innovative exploitation activity. However, exploitation also involves development processes and covers the search for technology. This empirical evidence suggests that in technological advances, diversity can mitigate the central rigidities and dependencies of routines. This happens especially when improving innovative solutions that accelerate the rate of invention, which shifts the company away from its past activities. In addition, IO was studied in Ahuja and Lampert (2001), suggesting that the pursuit of original technologies or experimentation with new existing technologies is likely to require slack resources but can generate returns. Several outstanding studies have looked into the effects of flows with organisational performance, particularly the alignment model proposed by Bontis et al. (2002) and business performance (Jansen et al., 2006).

However, examples demonstrate a growing interest in the literature in the relationship between exploration, exploitation and innovation and the need to go deeper into their relationships in a more direct way (Guisado-González et al., 2017; Wilden et al., 2018; Tian et al., 2020). For the purpose of this work, IO is analysed with the nine characteristics shown in Table A1. For all of these reasons, we propose the following hypotheses $H 4$ and $H 5$.

H4. Exploration has a positive impact on exploitation.

H5. Exploitation has a positive impact on the innovative outcome.

\section{Theoretical model to be tested and summary of the hypotheses}

Figure 1 shows the proposed predictive causal model of linear relationships. As independent variables, we consider the R\&D enablers and barriers and industrial property. Specifically, we will study how industrial property and R\&D barriers and enablers affect exploration then the effect of exploration on exploitation and the latter's effects on the IO as a result variable.

\section{Research method}

This section gives the characteristics of the sample, the measurement scales and the validation of the measurement scales.

\subsection{Characteristics of the sample of firms}

The dataset used in this paper contains firm-level data from the Spanish Technological Innovation Panel (PITEC). The survey was carried out by the Spanish Institute of Statistics

Innovative
outcome
through
exploration 


\section{EJMBE 31,1}

Figure 1.

Theoretical model to be tested

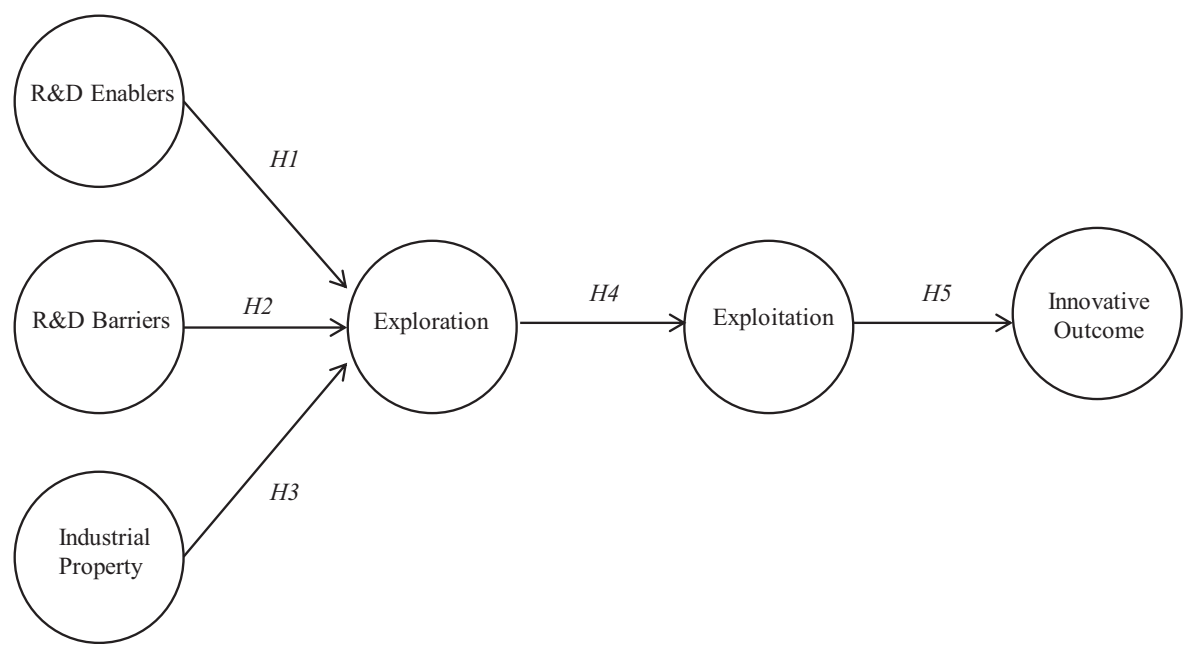

(INE), the Spanish Foundation for Science and Technology (FECYT) and the Foundation for Technological Innovation (COTEC). To create our sample, we selected the sub-samples from the database: (1) large firms with more than 250 employees and more than 50 million euros in turnover (European Commission, May 2003). These are firms that produce differentiated goods with high capital investment and innovation costs. They also have a high concentration of highly qualified workers; (2) firms with high total spending on innovation (above five million euros). In total, the group of firms that met both criteria contained 234 firms. As for the sector, the firms mostly belong to innovative sectors such as the industrial sector of software and telecommunications, pharmaceuticals, and aeronautical and space construction.

The six variables used in the empirical study and their items are shown in Table. The scales of measurements were those used in the questionnaire ite_cues15 called "Survey on Business Innovation 2015 in. All reflective measurements are classified according to the fourpoint Likert scale (Hair et al., 2017; Vargas and Lloria, 2019). On the other hand, to homogenise the scales of measurement of two variables (R\&D enablers and industrial property) with measurements of ratio, where zero represents the absence of the characteristic, a frequency distribution analysis of classes was carried out to group the data into categories and determine the number of classes according to Sturges (1926) and Mason et al. (1998).

\subsection{Validation of measurement scales}

To analyse and validate the data, we used the partial least square (PLS) technique (Wold, 1980, 1985; Fornell and Bookstein, 1982; Bagozzi et al., 1991). Table 1 provides the load $(\lambda)$ of most of the items. It was found that most of the loads $(\lambda)$ of the items are greater than 0.7 (Chin, 1998). The results show that all of the reflectively measured constructs' measurements are reliable and valid (Cepeda-Carrion et al., 2018). We examined the values of the variance inflation factor (VIF) and all the values of the items included are below 3.3, verifying the noncollinearity and removing problematic items (Diamantopoulos and Siguaw, 2006). We also include an assessment of convergent validity and internal consistency reliability. Smart PLS 3.0 (Ringle et al., 2015) obtained these values. The evaluation of the quality of the measurement model was carried out by analysing internal consistency, a convergent validity analysis (viable and valid constructs measurements by obtaining the AVE). 


\begin{tabular}{|c|c|c|c|c|c|c|c|}
\hline Constructs & Items & Loading & VIF & Cronbach's $\alpha$ & Composite reliability & AVE & Innovative \\
\hline \multirow[t]{4}{*}{ R\&D enablers } & EN1 & 0.822 & 1.508 & \multirow[t]{4}{*}{0.827} & \multirow[t]{4}{*}{0.878} & \multirow[t]{4}{*}{0.643} & through \\
\hline & EN2 & 0.758 & 2.042 & & & & loration \\
\hline & EN3 & 0.851 & 2.160 & & & & \\
\hline & EN5 & 0.774 & 2.035 & & & & \\
\hline \multirow[t]{4}{*}{ R\&D barriers } & BR5 & 0.811 & 2.370 & \multirow[t]{4}{*}{0.848} & \multirow[t]{4}{*}{0.888} & \multirow[t]{4}{*}{0.668} & \\
\hline & BR2 & 0.831 & 2.111 & & & & 47 \\
\hline & BR3 & 0.852 & 1.928 & & & & \\
\hline & BR6 & 0.702 & 1.671 & & & & \\
\hline \multirow[t]{4}{*}{ Industrial property } & IP1 & 0.759 & 1.853 & \multirow[t]{4}{*}{0.750} & \multirow[t]{4}{*}{0.827} & \multirow[t]{4}{*}{0.546} & \\
\hline & IP2 & 0.751 & 1.538 & & & & \\
\hline & IP4 & 0.720 & 1.622 & & & & \\
\hline & IP6 & 0.803 & 1.206 & & & & \\
\hline \multirow{4}{*}{ Exploration } & EXPLR1 & 0.913 & 3.300 & \multirow[t]{4}{*}{0.915} & \multirow[t]{4}{*}{0.940} & \multirow[t]{4}{*}{0.796} & \\
\hline & EXPLR3 & 0.874 & 3.233 & & & & \\
\hline & EXPLR4 & 0.898 & 3.296 & & & & \\
\hline & EXPLR6 & 0.884 & 3.022 & & & & \\
\hline \multirow[t]{4}{*}{ Exploitation } & EXPLOT1 & 0.795 & 1.730 & \multirow[t]{4}{*}{0.834} & \multirow[t]{4}{*}{0.889} & \multirow[t]{4}{*}{0.667} & \\
\hline & EXPLOT2 & 0.813 & 1.804 & & & & \\
\hline & EXPLOT3 & 0.802 & 1.695 & & & & \\
\hline & EXPLOT5 & 0.884 & 2.033 & & & & \\
\hline \multirow{6}{*}{ Innovation outcome } & IO1 & 0.793 & 2.929 & \multirow{6}{*}{0.906} & \multirow{6}{*}{0.928} & \multirow{6}{*}{0.681} & \\
\hline & IO3 & 0.824 & 3.279 & & & & \\
\hline & IO5 & 0.812 & 2.207 & & & & \\
\hline & IO6 & 0.869 & 2.972 & & & & \\
\hline & IO7 & 0.831 & 2.824 & & & & $\begin{array}{l}\text { Table } 1 . \\
\text { Assessment of }\end{array}$ \\
\hline & IO9 & 0.823 & 2.379 & & & & $\begin{array}{l}\text { Assessment of } \\
\text { convergent validity }\end{array}$ \\
\hline \multicolumn{7}{|c|}{$\begin{array}{l}\text { Note(s): EN: R\&D enablers; BR: R\&D barriers; IP: industrial property; EXPLR: exploration; EXPLT: } \\
\text { exploitation; innovative outcome: IO; AVE: average variance extracted; R\&D: research and development }\end{array}$} & $\begin{array}{r}\text { and internal } \\
\text { consistency reliability }\end{array}$ \\
\hline
\end{tabular}

An analysis of discriminant validity was also carried out (Table 2). These analyses show that the results satisfactorily meet the requirements established in the literature.

\section{Results}

Table 3 shows the results obtained after testing the hypotheses. At first sight, it can be seen that four of the five hypotheses are met with optimal results in the sample of firms analysed (H1, H2, H4 and H5). H3 is fulfilled but inversely. Each of them is explained below.

Hypothesis $H 1$ states that the R\&D enablers will have a positive impact on exploration: $H 1$ : $\beta(0.243), R^{2}(0.169)$, and $t\left(2.585^{* *}\right)$. The results confirm that this hypothesis can be accepted.

Regarding the second hypothesis, $H 2$, we stated in the theoretical framework, it is true that the R\&D barriers will have a negative impact on exploration: $H 2$ : $\beta(-0.252), R^{2}(0.169)$ and $t\left(2.215^{*}\right)$.

The third hypothesis was that industrial property would have a positive impact on exploration. The results are as follows: $H 3: \beta(-0.272), R^{2}(0.169)$, and $t(3.962 * * *)$. This indicates that the hypothesis is not met with optimal results. Surprisingly, the variable industrial property is strongly related, but negatively, to exploratory activity.

Hypotheses $H 4$ and $H 5$ highlight the importance of the $\mathrm{IO}$ as a result variable between exploration and exploitation. The results indicate that both hypotheses are met with optimal results: $H 4$ : $\beta$ (0.857), $R^{2}(0.735)$, and $t(27.969 * * *)$ and $H 5: \beta(0.849), R^{2}(0.722)$ and $t$ $\left(26.246^{* * *}\right)$. Both hypotheses assume the central core of our model, and their results were 


\section{EJMBE 31,1}

\begin{tabular}{lrccccc}
\hline & $\begin{array}{c}\text { R\&D } \\
\text { barriers }\end{array}$ & $\begin{array}{c}\text { R\&D } \\
\text { enablers }\end{array}$ & Exploitation & Exploration & $\begin{array}{c}\text { Industrial } \\
\text { property }\end{array}$ & $\begin{array}{c}\text { Innovative } \\
\text { outcome }\end{array}$ \\
\hline R\&D barriers & 0.817 & & & & & \\
$\begin{array}{l}\text { R\&D enablers } \\
\text { Exploitation }\end{array}$ & -0.236 & 0.802 & & & & \\
$\begin{array}{l}\text { Exploration } \\
\text { Industrial }\end{array}$ & -0.174 & 0.223 & 0.817 & & & \\
property & -0.164 & 0.233 & 0.778 & 0.892 & & \\
$\begin{array}{l}\text { Innovative } \\
\text { outcome }\end{array}$ & -0.172 & 0.173 & -0.077 & -0.169 & 0.739 & \\
$\begin{array}{l}\text { AVE } \\
\text { Square root }\end{array}$ & 0.668 & 0.643 & 0.801 & 0.808 & -0.083 & 0.826 \\
AVE & 0.817 & 0.802 & 0.817 & 0.796 & 0.546 & 0.681 \\
& & & & & 0.892 & \\
\end{tabular}

\begin{tabular}{lccccc}
\hline Hypothesis & $\begin{array}{c}\text { Sample } \\
\text { mean (M) }\end{array}$ & $\begin{array}{c}\text { Standardised path } \\
\text { coefficient ( }(\beta)\end{array}$ & $\begin{array}{c}t \text {-statistics (O/ } \\
\text { STERRR) }\end{array}$ & $R^{2}$ & $\begin{array}{c}Q^{2} \\
\text { Blindfolding }\end{array}$ \\
\hline $\begin{array}{l}\text { H1 R\&D } \\
\text { enablers } \rightarrow \text { exploration }\end{array}$ & 0.243 & 0.243 & $2.585^{* *}$ & 0.169 & 0.123 \\
H2 R\&D & -0.252 & -0.252 & $2.215^{*}$ & & \\
$\begin{array}{l}\text { barriers } \rightarrow \text { exploration } \\
\text { H3 Industrial }\end{array}$ & -0.272 & -0.272 & $3.962^{* * *}$ & & \\
$\begin{array}{l}\text { property } \rightarrow \text { exploration } \\
\text { H4 Exploration } \rightarrow \text { exploitation }\end{array}$ & 0.857 & 0.857 & $27.969^{* * *}$ & 0.735 & 0.482 \\
H5 Exploitation $\rightarrow$ innovative & 0.849 & 0.849 & $26.246^{* * *}$ & 0.722 & 0.487 \\
outcome & & & & &
\end{tabular}

Table 2.

Discriminant validity

outcome

Note(s): Values estimated using Smart PLS for a bootstrapping sample of 500

Table 3.

Significance: $t(0.05 ; 499)=1.647345 ; t(0.01 ; 499)=2.585711627 ; t(0.001 ; 499)=3.310124157$; Confidence level

Summary of results $95 \%, 99$ and $99.9 \% . * p<0.05 ; * * p<0.01 ; * * * p<0.001$ based on $t(499)$, two-tailed Student's $t$-test with $n-1$ degrees of freedom

statistically significant. In the sectors studied, the exploration processes offer optimal results in relation to the opening up of new markets and better products, services or processes.

Finally, we used the bootstrapping technique with a recommended sample size of 500 to evaluate the statistical significance of the path coefficients. In Table 3, we show the summary of the results of the hypotheses. The results of the predictive relevance of the dependent constructs, blindfolding $Q^{2}$ (Chin, 1998; Tenenhaus et al., 2005) (exploitation: 0.482, exploration: 0.123 , innovation outcome: 0.487 ) are positive, which confirms the predictive relevance of the model (Henseler et al., 2009). We also calculated the Goodness-of-Fit (GoF) index (Tenenhaus et al., 2005), which was 0.602.

Furthermore, we evaluated the model using PLSpredict (Ringle et al., 2015), following the guidelines for predictive model assessment in PLS-SEM of (Shmueli et al., 2019). In the first step, we found that all of the latent variables items outperform the most naïve benchmark (i.e. the training sample's indicator means), as all the items yield $Q^{2}$ predict $>0$. Comparing the square root of the average (RMSE) values from the PLS-SEM analysis with the naive LM benchmark, we found that the PLS-SEM analysis produces lower prediction errors for all the indicators (Evermann and Tate, 2016). We used one repetition (i.e. $r=1$ ) when the predictions should be based on a single model (Shmueli et al., 2019). The prediction summary for the latent variables (exploration, exploitation and innovative outcome) is $Q^{2}$ predict $0.121,0.105$ and 0.144 in terms of RMSE $(0.228,0.125$ and 0.268 , respectively), the values reveal that the model has 
good predictive abilities. Finally, the values obtained for these evaluation criteria demonstrate the fit of the proposed model.

\section{Conclusions}

The main objective of this work was to study the effect of industrial property and R\&D enablers and barriers on exploitation and exploration processes, considering the IO as a dependent variable.

Since March published his work in 1991 on the flows of learning, exploration and exploitation, there have been numerous subsequent studies. Even today, it remains an area of knowledge with great potential (Wilden et al., 2018). In this paper, we have explained in an original way how both learning flows behave by introducing the IO variable as a dependent variable. In addition, as drivers or brakes on the innovative process, we have also introduced industrial property and R\&D enablers and barriers.

After designing a theoretical framework in which we have defined the main variables and their relationships, we formulated five hypotheses. These hypotheses have been tested in a study of a quantitative nature on a sample of 234 large Spanish firms.

A major effort was made to integrate a construct of six variables measured with a fourpoint scale and to evaluate the measurement model using the PLS technique (internal consistency, convergent validity and discriminant validity), as well as to evaluate the structural model. The values reveal that the model has good predictive abilities. These scales, when validated, can, thus, be used by other researchers, and the model enables explanation and prediction in a fairly acceptable way. This combined attempt is original and contributes knowledge to exploration and exploitation with innovative outcomes, relating to R\&D enablers, R\&D barriers and industrial property as independent variables.

Five hypotheses were proposed, of which four have been met. Surprisingly, the one that is not fulfilled is actually met inversely to how it was initially proposed. Thus, we provide the following rationale: The interpretation of our findings involves two central considerations. Firstly, we can see the importance of exploration as a process in which new knowledge is sought and experienced. This allows advantage to be taken of what already exists by designing or improving new products, services or processes. Exploration can be driven by a group of enablers, above all financial and technological resources but inhibited by important barriers such as a lack of funding, information or qualified personnel, among others (Mansfield et al., 1981; Dougherty, 1992; Agarwal and Bayus, 2002; Vargas et al., 2016). Secondly, an inverse relationship is seen between industrial property and exploration. Various arguments have been put forward to explain this. One could be that the high costs of innovation and the competitive advantage it provides in the short term encourage firms to exploit their patents for a long period rather than make innovations. Another explanation may be the possibility of being imitated (Lemley and Shapiro, 2005). The patent requires publication of the innovation, and thereafter competitors could develop complementary innovations more easily, eliminating the possibility of competitive advantage arising from being the first (Shapiro, 2001). For this reason, some firms opt for other forms of protection, such as industrial secrecy (Lee et al., 2017).

The main originality and strength of our model lie in the effect of R\&D enablers and barriers and industrial property on the exploration process, the latter's relationship with exploitation and the final effect on IO as a variable of results. In this vein, recognising and managing the tension between exploration and exploitation is not an easy task; they are two critical challenges in the theory of organisational learning (Crossan et al., 1999). Therefore, the key aspect in our research is that an organisation should be involved in sufficient exploitation to ensure its current viability and, at the same time, devote sufficient attention to exploration to ensure the future viability of the organisation (Levinthal and March, 1993). The study
Innovative outcome through exploration 
EJMBE 31,1

confirms these proposals. This indicates that exploration leads to a series of results that, in turn, enhance exploitation. These findings, which may provide an opening to new markets and the creation or improvement of new products, services or processes, can open the doors to standardisation, new routines, efficiency and productivity. Ultimately, managing the tension between exploration and exploitation may give the stability that a company needs to enter new innovative processes in the short, medium and long term.

In terms of the limitations of this investigation, the scope of the sample may be a limiting factor, as the research only included a single country. Recent developments in PLS have emphasised the use of formative models for obtaining good predictive abilities (Chin et al., 2020). However, this is currently an issue under discussion (Shmueli et al., 2019). This work was limited, with a relatively small number of variables and reflective items. The combination of a greater number of new variables related to each other, measured with formative indicators (e.g. cooperation in innovation), would be of interest and is one of our proposals for future research. Furthermore, another model could also be defined based on the exploitation variable in this same data panel and applying new methods developed from the signalprocessing framework to the problem proposed in this work (Salazar et al., 2014). Recently, these methods have shown interesting results in data analysis for several applications that could complement the ones obtained by traditional statistical methods.

\section{References}

Agarwal, A. and Bayus, B. (2002), "The market evolution and take-off of new product innovations", Management Science, Vol. 48 No. 8, pp. 1024-1041.

Agarwal, R., Ganco, M. and Ziedonis, R.H. (2009), "Reputations for toughness in patent enforcement: implications for knowledge spillovers via inventor mobility", Strategic Management Journal, Vol. 30, pp. 1349-1374.

Ahuja, G. and Katila, R. (2001), "Technological acquisitions and the innovation performance of acquiring firms: a longitudinal study”, Strategic Management Journal, Vol. 22, pp. 197-220.

Ahuja, G. and Lambert, C.M. (2001), "Entrepreneurship in the large corporation: a longitudinal study of how established firms create breakthrough", Strategic Management Journal, Vol. 22, pp. 521-543.

Argyris, C. and Schön, D. (1978), Organizational Learning: A Theory of Action Perspective, Addison Wesley, Reading, MA.

Arzubiaga, U., Castillo-Apraiz, J. and Palma-Ruiz (2020), "Organisational learning as a mediator in the host-home country similarity-international firm performance link: the role of exploration and exploitation”, European Business Review, pp. 0955-534X, doi: 10.1108/EBR-09-2019-0238.

Asif, M. and Vries, H.J. (2014), "Creating ambidexterity through quality management", Total Quality Management, Vol. 26 No. 11, pp. 1-16.

Bagozzi, R.P., Yi, Y. and Singh, S. (1991), "On the use of structural equation models in experimental designs: two extensions international”, Journal of Research in Marketing, Vol. 8, pp. 125-140.

Basu, S., Phelps, C. and Kotha, S. (2011), "Towards understanding who makes corporate venture capital investments and why", Journal of Business Venturing, Vol. 26 No. 2, pp. 153-171.

Battistini, B., Hacklin, F. and Baschera, P. (2013), "The state of corporate venturing: insights from a global study", Research-Technology Management, Vol. 56 No. 1, pp. 31-39.

Bauer, M. and Leker, J. (2013), "Exploration and exploitation in product and process innovation in the chemical industry", R\&D Management, Vol. 43 No. 3, pp. 196-212.

Benitez, J., Castillo, A., Llorens, J. and Braojos, J. (2018), "IT-enabled knowledge ambidexterity and innovation performance in small U.S. firms: the moderator role of social media capability", Information and Management, Vol. 5, pp. 131-143. 
Bierly, P.E., Damanpour, F. and Santoro, M.D. (2009), "The application of external knowledge: organizational conditions for exploration and exploitation", Journal of Management Studies, Vol. 46, pp. 481-509.

Bontis, N., Crossan, M. and Hulland, J. (2002), "Managing an organizational learning system by aligning stocks and flows”, Journal of Management Studies, Vol. 39, pp. 438-469.

Cammarano, A., Caputo, M., Lamberti, E. and Michelino, F. (2017), "Open innovation and intellectual property: a knowledge-based approach”, Management Decision, Vol. 55 No. 6, pp. 1182-1208.

Castillo-Merino, D., Vilaseca-Requena, J. and Plana-Erta, D. (2010), "Financial constrains for innovative firs: the role of size, industry and ICT uses as determinants of firms' financial structure", in LytrasOrdonez, M.D.P., Ziderman, A., Roulstone, A., Maurer, H. and Imber, J. (Eds), Organizational, Business, and Technological Aspects of the Knowledge Society, SpringerVerlag Berlin Heidelberg, New York, NY.

Cepeda-Carrion, G., Cegarra-Navarro, J.G. and Cillo, V. (2018), "Tips to use partial least squares structural equation modelling (PLS-SEM) in knowledge management", Journal of Knowledge Management, Vol. 23 No. 1, pp. 67-89.

Chin, W. (1998), "The partial least square approach to structural equation modeling", in Marcoulides, G.A. (Ed.), Lawrence Erlbaum Associates, New Jersey, NJ, pp. 294-336.

Chin, W., Cheah, J., Liu, Y., Ting, H., Lim, X.J. and Cham, T.H. (2020), "Demystifying the role of causal predictive modeling using partial least squares structural equation modeling in information systems research", Industrial Management and Data System, Vol. 120 No. 12, pp. 2161-2209.

Coad, A., Pellegrino, G. and Savona (2016), "Barriers to innovation and firm productivity", Economics of Innovation and New Technology, Vol. 25 No. 3, pp. 321-334.

Crossan, M. and Apaydin, M. (2010), "A multi-dimensional framework of organizational innovation: a systematic review of the literature", Journal of Management Studies, Vol. 47 No. 6, pp. 1154-1191.

Crossan, M., Lane, H.W. and White, R.E. (1999), "An organizational learning framework: from intuition to institution", Academy of Management Review, Vol. 24, pp. 522-537.

D’Este, P., Iammarino, S., Savona, M. and von Tunzelmann, N. (2012), "What hampers innovation? Revealed barriers versus deterring barriers", Research Policy, Vol. 41 No. 2, pp. 482-488.

Danneels, E. (2002), "The dynamics of product innovation and firm competences", Strategic Management Journal, Vol. 23, pp. 1095-1121.

Das, P., Verburg, R., Verbraeck, A. and Bonebakker, L. (2017), "Barriers to innovation within large financial services firms: an in-depth study into disruptive and radical innovation projects at a bank", European Journal of Innovation Management, Vol. 21 No. 1, pp. 96-112.

Diamantopoulos, A. and Siguaw, J.A. (2006), "Formative vs reflective indicators in measure development: does the choice of indicators matter?", British Journal of Management, Vol. 13 No. 4, pp. 263-282.

Dominguez, R. and Massaroli, T. (2018), "The effects of organization context on knowledge Exploration and Exploitation”, Journal of Business Research, Vol. 90, pp. 215-225.

Dougherty, D. (1992), "Interpretive barriers to successful product innovations in large firms", Organization Science, Vol. 3 No. 2, pp. 179-202.

DSouza, D., Sigdayal, P. and Struckell, E. (2017), "Relative ambidexterity: a measure and a versatile framework", The Academy of Management Perspectives, Vol. 31 No. 2, pp. 124-136.

Evermann, J. and Tate, M. (2016), "Assessing the predictive performance of structural equation model estimators", Journal of Business Research, Vol. 69 No. 10, pp. 4565-4582.

Fornell, C. and Bookstein, F.I. (1982), "Two structural equation models: LISREL and PLS applied to consumer exit-voice theory", Journal of Marketing Research, Vol. 19, pp. 440-452.

Greve, H.R. (2007), "Exploration and exploitation in product innovation", Industrial and Corporate Change, Vol. 16 No. 5, pp. 945-975.
Innovative outcome through exploration 
EJMBE 31,1

Großmann, A.M., Filipovic, E. and Lazina, L. (2016), “The strategic use of patents and standards for new product development knowledge transfer", R\&D Management, Vol. 46 No. 2, pp. 312-325.

Guisado-González, M., González-Blanco, J. and Coca-Pérez, J.L. (2017), “Analyzing the relationship between exploration, exploitation and organizational innovation", Journal of Knowledge Management, Vol. 21 No. 5, pp. 1142-1162.

Hair, J.F. Jr, Hult, G.T., Ringle, C.M. and Sarstedt, M. (2017), A Primer on Partial Least Squares Structural Equation Modeling (PLS-SEM), 2ed, SAGE Publication, London.

Hedberg, B. (1981), "How organizations learn and unlearn", in Nystrom, P. and Starbuck, W. (Eds), Handbook of Organizational Design, Oxford University, New York, NY.

Henseler, J., Ringle, C.M. and Sinkovics, R.R. (2009), "The use the partial least squares path modelling”, in Sinkovics, R. and Pervez, N. (Eds), Advances in International Marketing, Emerald Group Publishing Limited, Bingley, pp. 277-319.

Hill, S.A. and Birkinshaw, J. (2014), “Ambidexterity and survival in corporate venture units”, Journal of Management, Vol. 40 No. 7, pp. 1899-1931.

Hölzl, W. and Janger, J. (2012), WIFO Working Pa, Pers, Austrian Institute of Economic Research (WIFO), WienVienna, p. 426.

Holgersson, M. and Wallin, M.W. (2017), "The patent management trichotomy: patenting, publishing, and secrecy", Management Decision, Vol. 55 No. 6, pp. 1087-1099.

Hsu, D.H. and Ziedonis, R.H. (2013), "Resources as dual sources of advantage: implications for valuing entrepreneurial- firm patents", Strategic Management Journal, Vol. 34, pp. 761-781.

Iansiti, M. (1997), Technology Integration: Making Critical Choices in a Dynamic World, Harvard Business School Press.

Jansen, J.F., Van den Bosch, F. and Volverda, H. (2006), "Exploratory innovation, exploitative innovation, and performance: effects of organizational antecedents and environmental moderators", Management Science, Vol. 51 No. 11, pp. 1661-1674.

Jansen, J.J.P., Tempelaar, M.P., Van den Bosch, F.A.J. and Volberda, H.W. (2009), "Structural differentiation and ambidexterity: the mediating role of integration mechanisms", Organization Science, Vol. 20 No. 4, pp. 797-811.

Katila, R. (2002), "New product search over time: past ideas in their prime?", Academy of Management Journal, Vol. 45 No. 5, pp. 995-1010.

Katila, R. and Chen, E.L. (2008), "Effects of search timing on innovation: the value of not being in sync with rivals", Administrative Science Quarterly, Vol. 53, pp. 593-625.

Kleijnen, M., Lee, N. and Wetzels, M. (2009), "An exploration of consumer resistance to innovation and its antecedent", Journal of Economic Psychology, Vol. 30 No. 3, pp. 344-357.

Knight, E. and Harvey, W. (2015), "Managing exploration and exploitation paradoxes in creative organisations", Management Decision, Vol. 53 No. 4, pp. 809-827.

Laursen, K., Leone, M.I. and Torrisi, S. (2010), "Technological exploration through licensing: new insights from the licensee's point of view", Industrial and Corporate Change, Vol. 19 No. 3, pp. 871-897.

Lavie, D. and Rosenkopf, L. (2006), "Balancing exploration and exploitation in alliance formation", Academy of Management Journal, Vol. 49 No. 4, pp. 797-818.

Lavie, D., Stettner, U. and Tushman, M.L. (2010), "Exploration and exploitation within and across organizations", The Academy of Management Annals, Vol. 4 No. 1, pp. 109-155.

Lavie, D., Kang, J. and Rosenkopf, L. (2011), "Balance within and across domains: the performance implications of exploration and exploitation in alliances", Organization Science, Vol. 22 No. 6, pp. 1517-1538. 
Lee, J.M., Joo, S.H. and Kim, Y. (2017), “The complementary effect of intellectual property protection mechanisms on product innovation performance", R\&D Management, Vol. 48 No. 3, pp. 320-330.

Lee, S.U., Park, G. and Kang, J. (2018), “The double-edged effects of the corporate venture capital unit's structural autonomy on corporate investors' explorative and exploitative innovation", Journal of Business Research, Vol. 88, pp. 141-149.

Lemley, M.A. and Shapiro, C. (2005), "Probabilistic patents", The Journal of Economic Perspectives, Vol. 19, pp. 75-98.

Levinthal, D.A. and March, J.G. (1993), "The myopia of learning", Strategic Management Journal, Vol. 14, pp. 95-112.

Lloria, M.B. and Peris-Ortiz, M. (2014), "Knowledge creation. The ongoing search for strategic renewal", Industrial Management and Data Systems, Vol. 114 No. 7, pp. 1022-1035.

Lubatkin, M.H., Simsek, Z., Ling, Y. and Veiga, J.F. (2006), "Ambidexterity and performance in smallto medium-sized firms: the pivotal role of top management team behavioral integration", Journal of Management, Vol. 32 No. 5, pp. 646-672.

Maggitti, P.G., Smith, K.G. and Katila, R. (2013), “The complex search process of invention”, Research Policy, Vol. 42 No. 1, pp. 90-100.

Mancusi, M.L. and Vezzulli, A. (2014), "R\&D and Credit rationing in SMEs", Economic Inquiry, Vol. 52 No. 3, pp. 1153-1172.

Mansfield, E. (1981), "Composition of R\&D expenditures: relationship to size of firm, concentration and innovative output", The Review of Economics and Statistics, Vol. 63 No. 4, pp. 610-615.

March, J.G. (1991), "Exploration and exploitation in organizational learning", Organizational Science, Vol. 2 No. 1, pp. 71-87.

March, J.G. (1996), "Continuity and change in theories of organizational action”, Administrative Science Quarterly, Vol. 41 No. 2, pp. 278-287.

March, J.G. (2006), "Rationality, foolishness, and adaptive intelligence”, Strategic Management Journal, Vol. 27, pp. 201-214.

Marín-Idágarra, D.A., Hurtado, J.M. and Cabello, C. (2016), "The antecedents of exploitationexploration and their relationship with innovation: a study of managers' cognitive maps", Creativity and Innovation Management, Vol. 25 No. 1, pp. 18-37.

Mason, R., Lind, D. and Marchal, W. (1998), Study Guide for Use with Statistical Techniques in Business and Economics, 10 edition, McGraw-Hill/Irwin, p. 408.

Modic, D., Hafner, A., Damij, N. and Cehovin Zajc, L. (2019), "Innovations in intellectual property rights management. Their potential benefits and limitations", European Journal of Management and Business Economics, Vol. 28 No. 2, pp. 189-203.

OReilly, C.A. and Tushman, M.L. (2013), "Organizational ambidexterity: past, present, and future", The Academy of Management Perspectives, Vol. 27 No. 4, pp. 324-338.

Parida, V., Lahti, T. and Wincent, J. (2016), "Exploration and exploitation and firm performance variability: a study of ambidexterity in entrepreneurial firms", International Entrepreneurship and Management Journal, Vol. 12, pp. 1147-1164.

Pati, R. and Garud, N. (2020), "Role of feedback on innovative outcomes: moderating role of resourceconstrained environments", IEEE Transactions on Engineering Management, pp. 1-14, 0018-9391.

Peeters, T. and Martin, X. (2017), "Strategies for knowledge use in R\&D and their implications for innovative performance", R\&D Management, Vol. 47 No. 1, pp. 47-60.

Quintana-García, C. and Benavides-Velasco, C.A. (2008), "Innovative competence, exploration and exploitation: the influence of technological diversification", Research Policy, Vol. 37 No. 3, pp. 492-507.

\section{Innovative outcome through exploration}


EJMBE 31,1

Raisch, S. and Birkinshaw, J. (2008), "Organizational ambidexterity: antecedents, outcomes, and moderators”, Journal of Management, Vol. 34 No. 3, pp. 375-409.

Ramadani, V., Hyrije, A.A., Léo-Paul, D., Gadaf, R. and Sadudin, I. (2017), "The impact of knowledge spillovers and innovation on firm-performance: findings from the Balkans countries", International Entrepreneurship Management Journal, Vol. 13, pp. 299-325.

Randhawa, K., Wilden, R. and Hohberger, J. (2016), "A bibliometric review of open innovation: setting a research agenda”, Journal of Product Innovation Management, Vol. 33, pp. 750-772.

Ringberg, T., Reihlen, M. and Rydén, P. (2019), "The technology-mindset interactions: leading to incremental, radical or revolutionary innovations", Industrial Marketing Management, Vol. 79, pp. 102-113.

Ringle, C.M., Wende, S. and Becker, J.M. (2015), Smart PLS 3, SmartPLS GmbH, Boenningstedt.

Rosenkopf, L. and Nerkar, A. (2001), "Beyond local search: boundary-Spanning, Exploration, and impact in the optical disk industry", Strategic Management Journal, Vol. 22 No. 4, pp. 287-306.

Salazar, A., Safont, G. and Vergara, L. (2014), "Surrogate techniques for testing fraud detection algorithms in credit card operations", 48th Annual IEEE International Carnahan Conference on Security Technology, Rome, Italy, ICCST 2014, pp. 124-129, art. no. 6986987.

Sandberg, B. and Aarikka-Stenroos, L. (2014), "What makes it so difficult? A systematic review on barriers to radical innovation", Industrial Marketing Management, Vol. 43 No. 8, pp. 1293-1305.

Shapiro, C. (2001), "Navigating the patent thicket: cross licenses, patent pools, and standard-setting" in Adam, J., Lerner, J. and Scott, S. (Eds), Innovation policy and the Economy, MIT Press, Vol. 1, pp. 119-150.

Shmueli, G., Hair, j.F., Cheah, J.H., Ting, H., Vaithilingam, S. and Ringle, C. (2019), "Predictive model assessment in PLS-SEM: guidelines for using PLSpredict", European Journal of Marketing, Vol. 53 No. 11, pp. 2322-2347.

Shrivastava, P. (1983), "A typology of organizational learning systems", Journal of Management Studies, Vol. 20 No. 1, pp. 7-28.

Simsek, Z., Heavey, C., Veiga, J.F. and Souder, D. (2009), “A typology for aligning organizational ambidexterity's conceptualizations, antecedents, and outcomes”, Journal of Management Studies, Vol. 46 No. 5, pp. 864-894.

Somaya, D. (2012), "Patent strategy and management: an integrative review and research agenda", Journal of Management, Vol. 38, pp. 1084-1114.

Sturges, H. (1926), “The choise of a class interval”, American Statistical Association, Vol. 21, pp. 65-66.

Teece, D. (2012), "Dynamic capabilities: routines versus entrepreneurial action", Journal of Management Studies, Vol. 49 No. 8, pp. 1395-1401.

Tenenhaus, M., Vinzi, V., Chatelin, Y. and Lauro, C. (2005), "PLS path modeling", Computational Statistics and Data Analysis, Vol. 48 No. 1, pp. 159-205.

Tian, H., Kofi, C.S., Kwabw, W.W. and Ato, S. (2020), "Organizational learning ambidexterity and openness, as determinants of SMEs' innovation performance”, European Journal of Innovation Management, April, pp. 1460-1060.

Vargas, N. and Lloria, M.B. (2019), "El Resultado Innovador como variable mediadora entre los flujos de aprendizaje explotación y exploración”, Proceedings of the XXXIII Congreso Anual European Academy of Management and Business Economics, Sevilla, Spain, AEDEM, pp. 913-935.

Vargas, N., Lloria, M.B. and Roig-Dobón, S. (2016), "Main drivers of human capital, learning and performance", The Journal of Technology Transfer, Vol. 41 No. 5, pp. 961-978.

Vargas, N., LloriaSalazar, M.B.A. and Vergara, L. (2018), "Effect of exploitation and exploration on the innovative as outcomes in entrepreneurial firms", International Entrepreneurship and Management Journal, Vol. 14 No. 4, pp. 1053-1069. 
Voss, G.B., Sirdeshmukh, D. and Voss, Z.G. (2008), "The effects of slack resources and environmental threat on product exploration and exploitation”, Academy of Management Journal, Vol. 51 No. 1, pp. 147-164.

Wang, H. and Li, J. (2008), "Untangling the effects of over exploration and overexploitation on organizational performance: the moderating role of environmental dynamism", Journal of Management, Vol. 34 No. 5, pp. 925-951.

Wang, C.H. and Hsu, L.C. (2014), "Building exploration and exploitation in the high-tech industry: the role of relationship learning", Technological Forecasting and Social Change, Vol. 81, pp. 331-340.

Wang, P., Van de Vrande, V. and Jansen, J. (2017), "Balancing exploration and exploitation in inventions: quality of inventions and team composition”, Research Policy, Vol. 46 No. 10, pp. 1836-1850.

Wilden, R., Hohberger, J., Devinney, T.M. and Lavie, D. (2018), "Revisiting James March (1991): whither exploration and exploitation?”, Strategic Organization, Vol. 16 No. 3, pp. 352-369.

Wold, H. (1980), "Model construction and evaluation when theoretical knowledge is scarce", in Kmenta, J. and Ramsey, J.B. (Eds), Evaluation of Econometric Models, Academic Press, Cambridge, pp. 47-74.

Wold, H. (1985), "Factors influencing the outcome of economic sanctions. In Sixto Ríos Honorary", Trabajos de Estadística and de Investigación Operativa, Vol. 36 No. 3, pp. 325-337.

Wolf, T., Cantner, U., Graf, H. and Rothgang, M. (2019), "Cluster ambidexterity towards explorationand exploitation: strategies and cluster management", Journal of Technology Transfer, Vol. 44, pp. 1840-1866.

$\mathrm{Xu}, \mathrm{F}$. (2014), "The strengthes and weaknesses of Japanese innovation”, Kindai Management Review, Vol. 2, pp. 97-105.

Yu, G.J. and Hong, K. (2016), "Patents and R\&D expenditure in explaining stock price movement", Finance Research Letters, Vol. 19, pp. 197-203.

\section{Further reading}

Kleinbaum, D.G., Kupper, N.N. and Muller, K.E. (1988), Applied Regression Analysis and Other Multivariable's Methods, PWS KENT.

Mone, M.A., McKinley, W. and Barker, V.L. (1998), "Organizational decline and innovation: a contingency framework”, Academy of Management Review, Vol. 23, pp. 115-132.

O'Reilly, C.A. III and Tushman, M.L. (2008), "Ambidexterity as a dynamic capability: resolving the innovator's dilema”, Research in Organizational Behavior, Vol. 28, pp. 185-206.

Vargas, N. and Lloria, M.B. (2014), "Dynamizing intellectual capital through enablers and learning flows", Industrial Management and Data Systems, Vol. 114 No. 1, pp. 2-20.

Vargas, N. and Lloria, M.B. (2017), "Performance and intellectual capital: how enablers drive value creation in organisations", Knowledge and Process Management, Vol. 24 No. 2, pp. 114-124.

Vera, D. and Crossan, M. (2004), "Strategic leadership and organizational learning", The Academy of Management Review, Vol. 29 No. 2, pp. 222-240.

Wold, H. (1982), "Soft modeling: the basic design and some extensions", in Jöreskog, K.G. and Wold, H. (Eds), Systems under Indirect Observations: Part II, North-Holland, Amsterdam, pp. 1-54. 


\section{EJMBE 31,1}

\section{Appendix}

56

\begin{tabular}{|c|c|c|}
\hline Variables & Items & Objectives \\
\hline \multirow[t]{7}{*}{$\mathrm{R} \& \mathrm{D}$ barriers } & BR1 & Missing funds within firm \\
\hline & BR2 & Lack of external financing to the firm \\
\hline & BR3 & High innovation cost \\
\hline & $\mathrm{BR} 4$ & Missing qualified staff \\
\hline & BR5 & Lack of information technology \\
\hline & BR6 & Lack of information markets \\
\hline & BR7 & Difficulty in finding partners for co-operation in innovation \\
\hline \multirow[t]{6}{*}{ R\&D enablers } & EN1 & $\begin{array}{l}\text { Internal R\&D costs: Remuneration researchers, technical and auxiliary, and } \\
\text { other trends }\end{array}$ \\
\hline & EN2 & Acquisition costs of machinery and equipment \\
\hline & EN3 & Acquisition costs of others external knowledge for innovation \\
\hline & EN4 & Acquisition costs of external R\&D \\
\hline & EN5 & Introduction cost of innovations in the market cost \\
\hline & EN6 & Training costs for innovation activities \\
\hline \multirow{7}{*}{$\begin{array}{l}\text { Industrial } \\
\text { property }\end{array}$} & IP1 & Spanish patents \\
\hline & IP2 & European patents \\
\hline & IP3 & American patents \\
\hline & IP4 & Patent cooperation treaty \\
\hline & IP5 & Register of utility models \\
\hline & IP6 & Brands \\
\hline & IP7 & Copyright \\
\hline \multirow[t]{5}{*}{ Exploitation } & EXPLT1 & Feedback information inside the company or group \\
\hline & EXPLT2 & Feedback supplier information \\
\hline & EXPLT3 & Feedback customer information \\
\hline & EXPLT4 & Feedback competitor information \\
\hline & EXPLT5 & Feedback consultants, laboratories \\
\hline \multirow[t]{6}{*}{ Exploration } & EXPLR1 & Share information universities \\
\hline & EXPLR2 & Share public research organisations \\
\hline & EXPLR3 & Share information technology centres \\
\hline & EXPLR4 & Share information conferences, fairs and exhibitions \\
\hline & EXPLR5 & Share information: Scientific journals \\
\hline & EXPLR6 & Share information: Professional \\
\hline \multirow{9}{*}{$\begin{array}{l}\text { Innovative } \\
\text { outcome }\end{array}$} & IO1 & Larger range of goods or service \\
\hline & IO2 & Replacement of outdated products or processes \\
\hline & IO3 & Penetration in new markets \\
\hline & IO4 & Greater market share \\
\hline & IO5 & Higher quality of goods or service \\
\hline & IO6 & Greater flexibility in the production or provision of services \\
\hline & IO7 & Increased production capacity or service provision \\
\hline & IO8 & Lower labour costs per unit produced \\
\hline & IO9 & Fewer materials per unit produced \\
\hline
\end{tabular}

\section{Corresponding author}

M. Begoña Lloria can be contacted at: maria.b.lloria@uv.es

For instructions on how to order reprints of this article, please visit our website:

www.emeraldgrouppublishing.com/licensing/reprints.htm

Or contact us for further details: permissions@emeraldinsight.com 